\title{
Improved efficacy of ultrafiltered xylanase-pectinase concoction in biobleaching of plywood waste soda pulp
}

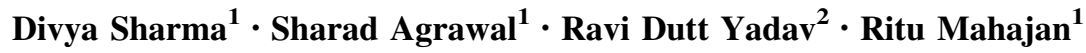

Received: 16 November 2016/ Accepted: 8 January 2017/Published online: 7 April 2017

(C) The Author(s) 2017. This article is published with open access at Springerlink.com

\begin{abstract}
The effect of ultrafiltered xylanase-pectinase concoction produced simultaneously by a bacterial isolate using agro-waste-based media was assessed in prebleaching of plywood waste pulp. Ultrafiltered enzymes caused $12.5 \%$ reduction in kappa number at reduced enzyme dose of xylanase-pectinase (4.0-0.8 IU) per gram of pulp under optimized conditions at $\mathrm{pH} 8.5$, temperature $55^{\circ} \mathrm{C}$, and treatment period of $2 \mathrm{~h}$. Using this methodology, amount of $\mathrm{Cl}_{2}-\mathrm{ClO}_{2}$ consumption can be reduced up to 30 and $28.86 \%$. Significant improvement in physical and optical properties of pulp was obtained along with an additional reduction in BOD and COD values up to 18.13 and $21.66 \%$ using this novel biodelignification approach. This is the first report showing the advantages of using ultrafiltered xylanase-pectinase over crude enzymes in enhancing the bleaching capacity of pulp. This study focussing on the development of good quality paper with less pollution generating strategy will definitely prove a boon for industries.
\end{abstract}

Keywords Biobleaching · Kappa number · Soda anthraquinone pulp $\cdot$ Ultrafiltration $\cdot$ Xylanase $\cdot$ Pectinase

Ritu Mahajan

ritupanipat@rediffmail.com

1 Department of Biotechnology, Kurukshetra University, Kurukshetra, Haryana 136119, India

2 Trident Limited, Mansa Road, Dhaula, Barnala, Punjab 148105, India

\section{Introduction}

The evolution of unconventional biotechnological techniques in various processing industries plays a huge role in solving the vital problems of pollution created by the industries. As far as the environment is concerned, paper manufacturing industries are observed to be the worst offenders. Several toxic organo-chlorine compounds are formed during bleaching by the conventional chemical methods, which are found to be bioaccumulating and harmful for the biological systems (Fiedler et al. 1990; Bajpai et al. 2006). These chlorinated organic by-products include mainly dioxins, which cause severe environmental damage, high COD values of water, and ultimately responsible for expensive waste water treatment (Zhang et al. 2008). Although the economic value of a nation is improved by industrialization, the effluents produced by some industries also cause a significant harm to the environment (Hossain and Rao 2014; Raj et al. 2014; Hossain and Ismail 2015). There is massive challenge for pulp and paper mills in handling dangerous pollutants, looking at the environmental load and legal necessities (Kamali and Khodaparsat 2015). To reduce the pollution created by these industries as well as to enhance the quality of paper, microbial enzymes have gained a unique place due to their potential application in paper and pulp industries in an ecofriendly manner.

Lignin, a complex polyphenolic structure, is covalently linked to cell wall polysaccharides as lignin-carbohydrate complexes. Xylanase helps in bleaching by hydrolyzing the xylan from lignin-xylan complex (Yin et al. 2011), thereby decreases the consumption of chlorine and consequently lowers the release of hazardous chemicals in the effluent, hence creating an ecofriendly technology (Beg et al. 2001). Apart from xylanase, pectinase has also been used in pulp 
and paper industries. During alkaline conditions of pulping, the release of pectin from fiber structure creates pool of anionic trash in the aqueous phase, which is responsible for the high consumption of cationic additives, and ultimately, these anionic-cationic complexes cause blockage of the drainage system. Pectinase helps to degrade the pectin released into the aqueous phase of pulp (Lund et al. 2004). Crude xylanase-pectinase enzymes have been successfully used in biobleaching of plywood industrial waste soda anthraquinone pulp (Agrawal et al. 2016) and in biobleaching of mixed hardwood kraft pulp (Kaur et al. 2010).

In this report, ultrafiltered (UF) enzymes have been applied in biobleaching of soda anthraquinone (SAQ) pulp. The aim of this work is to compare and evaluate the bleaching potential of ultrafiltered xylano-pectinolytic enzymes with crude xylanase-pectinase concoction, on plywood veneer SAQ pulp. No such type of work using ultrafiltered xylanase-pectinase mixture has been reported in the literature until now. This is the first report showing the role of UF xylanase-pectinase synergism in reducing toxic bleaching chemicals consumption and ultimately the cost of waste water treatment, along with the production of superior quality paper with significant improvement in various physical and optical properties of plywood pulp.

\section{Materials and methods}

\section{Microbial strain and other materials}

Production of enzymes was carried out using cellulase free Bacillus pumilus AJK strain (MTCC Accession No. 10414). Birchwood xylan was purchased from SigmaAldrich, and all other chemicals used were of high purity grade. Agro-residues, such as wheat bran and citrus peel, were purchased from local market.

\section{Enzyme production, ultrafiltration, and enzyme activity}

The xylanase and pectinase enzymes were produced in $250 \mathrm{ml}$ Erlenmeyer flasks containing $50 \mathrm{ml}$ basal medium (g/l: peptone, 5.0; $\mathrm{MgSO}_{4} .7 \mathrm{H}_{2} \mathrm{O}, 2.45 ; \mathrm{pH} 7.0$ ) supplemented with $2 \%$ wheat bran and $2 \%$ citrus peel under submerged fermentation. After autoclaving, inoculation was done with $2 \%$ inoculum of $21 \mathrm{~h}$ old and incubated at $37{ }^{\circ} \mathrm{C}$ for $48 \mathrm{~h}$ under continuous shaking conditions. Microfiltration was done using $0.2 \mu$ membrane cartridge to get the clear cell free extract. The clear supernatant was passed through $3 \mathrm{kDa}$ nominal molecular weight cut-off membrane to concentrate the extract tenfold and to remove low-molecular weight impurities. Enzyme activity was determined by measuring the release of reducing sugars after enzymatic reaction using 3,5-dinitro-salicylic acid method (Miller 1959). Assays were performed under similar conditions as described by Kaur et al. (2010).

\section{Pulp sample and optimization of various reaction parameters using UF enzymes}

The biobleaching ability of UF enzymes was determined by incubating unbleached SAQ pulp sample consisting of $90 \%$ plywood industrial waste (veneer), $5 \%$ bamboo, and $5 \%$ hardwood with xylanase-pectinase enzymes under optimized reaction conditions. Pulp consistency used for all the experiments was $10 \%$, and anthraquinone concentration was $0.08 \%$. Reaction parameters for enzymatic bleaching of SAQ pulp were optimized using one variable at a time approach. Different reaction conditions, such as temperature, $\mathrm{pH}$, enzyme dose, and treatment time, were optimized to obtain the best conditions. SAQ pulp ( $25 \mathrm{~g})$ was treated with xylanase-pectinase preparations under different $\mathrm{pH}$ values ranging from 7.5 to 10.0 . Similarly, the pulp was treated with different enzyme dosages ranging between 2.0 and 7.0 IU of xylanase and $0.4-1.4$ IU of pectinase per gram of pulp for different time periods from 60 to $200 \mathrm{~min}$ and in variable temperature range from 45 to $70{ }^{\circ} \mathrm{C}$. Control samples were also run under the same conditions using heat-inactivated enzymes. After washing the pulp samples with water, handsheets were made using the standard TAPPI methods (TAPPI test methods 1996). Kappa number was determined (TAPPI T236) to find the best effective bleaching condition.

\section{Bleaching steps and analysis of different physical properties of plywood veneer pulp}

Bleaching of control, crude enzymes, and UF enzymetreated pulp samples (under optimum reaction conditions) was carried out using various steps-Chlorination; Alkali extraction; Chlorine dioxide treatment 1; and Chlorine dioxide treatment 2 . To evaluate the percent reduction in chlorine consumption in UF enzyme-treated pulps, chlorination was done with different reducing concentrations of chlorine. In the second step, alkali extraction was done by treating the pulp samples with $2.5 \% \mathrm{NaOH}$ and $0.8 \% \mathrm{H}_{2} \mathrm{O}_{2}$ at $80{ }^{\circ} \mathrm{C}$ for $2 \mathrm{~h}$. Alkali-treated pulps were washed with water to remove extra alkali present in the pulp, and a known amount of pulp was used to make handsheets for measuring the brightness and the left over pulp was treated with chlorine dioxide, in two steps $\left(1.0\right.$ and $\left.0.3 \% \mathrm{ClO}_{2}\right)$ stages to remove residual lignin at $70{ }^{\circ} \mathrm{C}$ for $3 \mathrm{~h}$. Reduction in consumption of chlorine dioxide in both stages was also determined. After all bleaching steps, pulp filtrates were used to determine the BOD and COD values of pulp 
effluents. Handsheets were prepared and analyzed for different physical properties viz., Pulp freeness (TAPPI Method 227), Brightness (TAPPI Method 452), Breaking length (TAPPI Method 404), Burst factor (TAPPI Method 403), Tear factor (TAPPI Method 496), Viscosity (TAPPI Method 230), and Kappa number (TAPPI Method 236). All experiments were performed in triplicates.

\section{Results and discussion}

\section{Optimization of enzymatic processes for biobleaching}

Maximum bleaching of plywood veneer SAQ pulp was observed with enzyme dose of 4.0 IU xylanase and 0.8 IU pectinase per $\mathrm{g}$ of pulp at $\mathrm{pH} 8.5$ using UF enzymes (Fig. 1a), whereas 6.0 IU xylanase and $2.4 \mathrm{IU}$ pectinase per $g$ of pulp were found to be optimum for the bleaching of SAQ veneer pulp using crude enzymes at $\mathrm{pH} 8.5$ (Agrawal et al. 2016). Ultrafiltration strategy resulted in the removal of low-molecular weight impurities from the crude xylanase-pectinase preparation, which was interfering with the kinetic efficiency of enzymes. Kaur et al. (2010) reported maximum prebleaching of mixed hardwood and bamboo kraft pulp with enzyme dose of 4.5 IU xylanase and $0.9 \mathrm{IU}$ pectinase at $\mathrm{pH}$ 8.5. Xylanase dose of $10 \mathrm{IU} / \mathrm{g}$
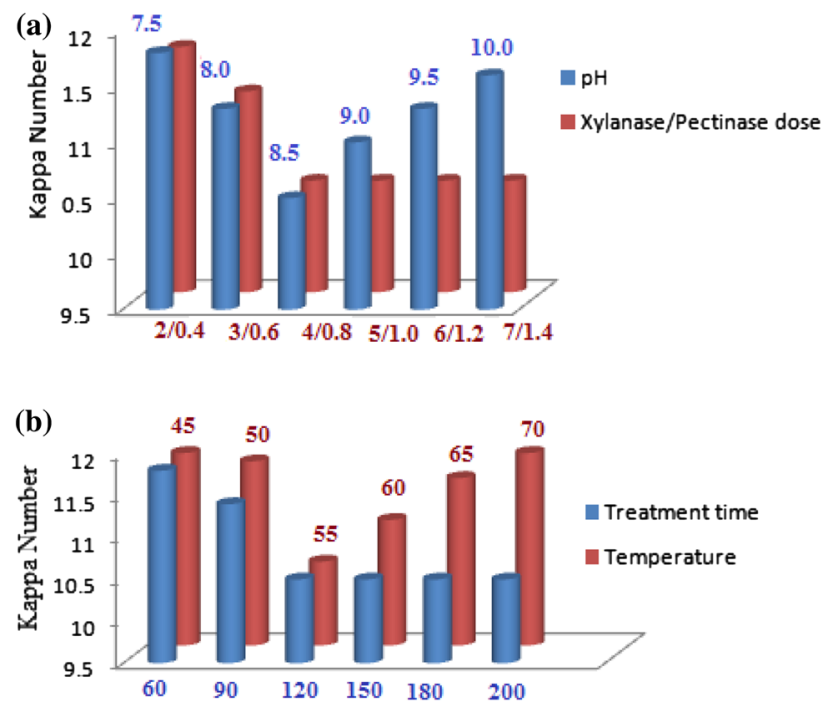

Fig. 1 Effect of enzyme dose, $\mathrm{pH}$, treatment time, and temperature on pulp biobleaching. a These experiments were performed by treating the pulp at $55{ }^{\circ} \mathrm{C}$ for $180 \mathrm{~min}$. For enzyme dose optimization, $\mathrm{pH}$ was set at 8.5 , and for $\mathrm{pH}$ optimization, $4.0 \mathrm{IU}$ of xylanase and $0.8 \mathrm{IU}$ of pectinase dose per $\mathrm{g}$ of pulp were used. b These experiments were performed at $\mathrm{pH} 8.5$ and enzyme dose of $4 \mathrm{IU}$ of xylanase and $0.8 \mathrm{IU}$ of pectinase per $\mathrm{g}$ of pulp. For treatment time optimization, reaction was allowed to proceed at $55{ }^{\circ} \mathrm{C}$, and for temperature determination, treatment time was $120 \mathrm{~min}$ of pulp at $\mathrm{pH} 9.0$ was found to be optimum for biobleaching of mixed wood kraft pulp (Nagar et al. 2013).

A treatment time of $120 \mathrm{~min}$ and temperature $55^{\circ} \mathrm{C}$ was found to be optimum for maximum bleaching efficiency of UF enzymes (Fig. 1b). Higher dose of enzymes and longer treatment time did not enhance the biobleaching efficiency. Kaur et al. (2010) reported a treatment time of $180 \mathrm{~min}$ at $55^{\circ} \mathrm{C}$ for biobleaching of mixed hardwood and bamboo kraft pulp. Treatment time of $2 \mathrm{~h}$ at $55^{\circ} \mathrm{C}$ was also found optimum in biobleaching of mixed wood kraft pulp (Nagar et al. 2013). Biobleaching of eucalyptus kraft pulp was observed best using enzyme dose of 15 IU xylanase and 20 nkats of laccase per $g$ of pulp (Gupta et al. 2015).

Ultrafiltered enzymatic treatment of SAQ veneer pulp resulted in $12.5 \%$ reduction in kappa number over control (non-enzyme treated). Nearly, 9.17\% reduction in kappa number over control was obtained by treating SAQ veneer pulp with crude enzymes. Therefore, reduction in kappa number is nearly $3.66 \%$ more with UF enzymes in comparison with crude enzymes. The UF preparation enhanced the affinity of enzymes for their selective substrates and resulted in enhancement of delignification efficiency. Kaur et al. (2010) reported $8.5 \%$ reduction in kappa number after synergistic action of crude xylanase-pectinase enzymes on kraft pulp. Nearly, 15 and $16.27 \%$ reduction in kappa number was observed using combination of xylanase and laccase in biobleaching of eucalyptus kraft pulp and Hibiscus cinnabinus SAQ pulp, respectively (Gupta et al. 2015; Andreu and vidal 2014).

\section{Biobleaching of plywood veneer SAQ pulp}

Though the treatment of plywood veneer SAQ pulp with crude xylanase-pectinase synergism resulted in 25 and $23.8 \%$ less chlorine and chlorine dioxide consumption, respectively (Agrawal et al. 2016), UF enzyme-treated pulp under optimized conditions, when subjected to chemical bleaching, resulted in 30 and $28.86 \%$ reduction in consumption of chlorine and chlorine dioxide, respectively, for obtaining the same \% ISO brightness as obtained by the conventional chemical bleaching (Table 1). Biobleaching of mixed hardwood kraft pulp using cellulase free xylanase produced by Bacillus subtilis ASH resulted in $28.6 \%$ reduction in chlorine consumption (Sanghi et al. 2009). Kaur et al. (2010) reported $25 \%$ reduction in chlorine consumption by the synergistic action of xylanase and pectinase enzymes on mixed hardwood kraft pulp. Chlorine consumption was reduced up to $12.5 \%$ using xylanase in prebleaching of wheat straw pulp (Walia et al. 2015). Biobleaching of eucalyptus kraft pulp resulted in 20 and $10 \%$ reduction in chlorine consumption using xylanase producing Bacillus halodurans FNP 135 culture and produced by SmF and SSF, respectively (Sharma et al. 2015). 


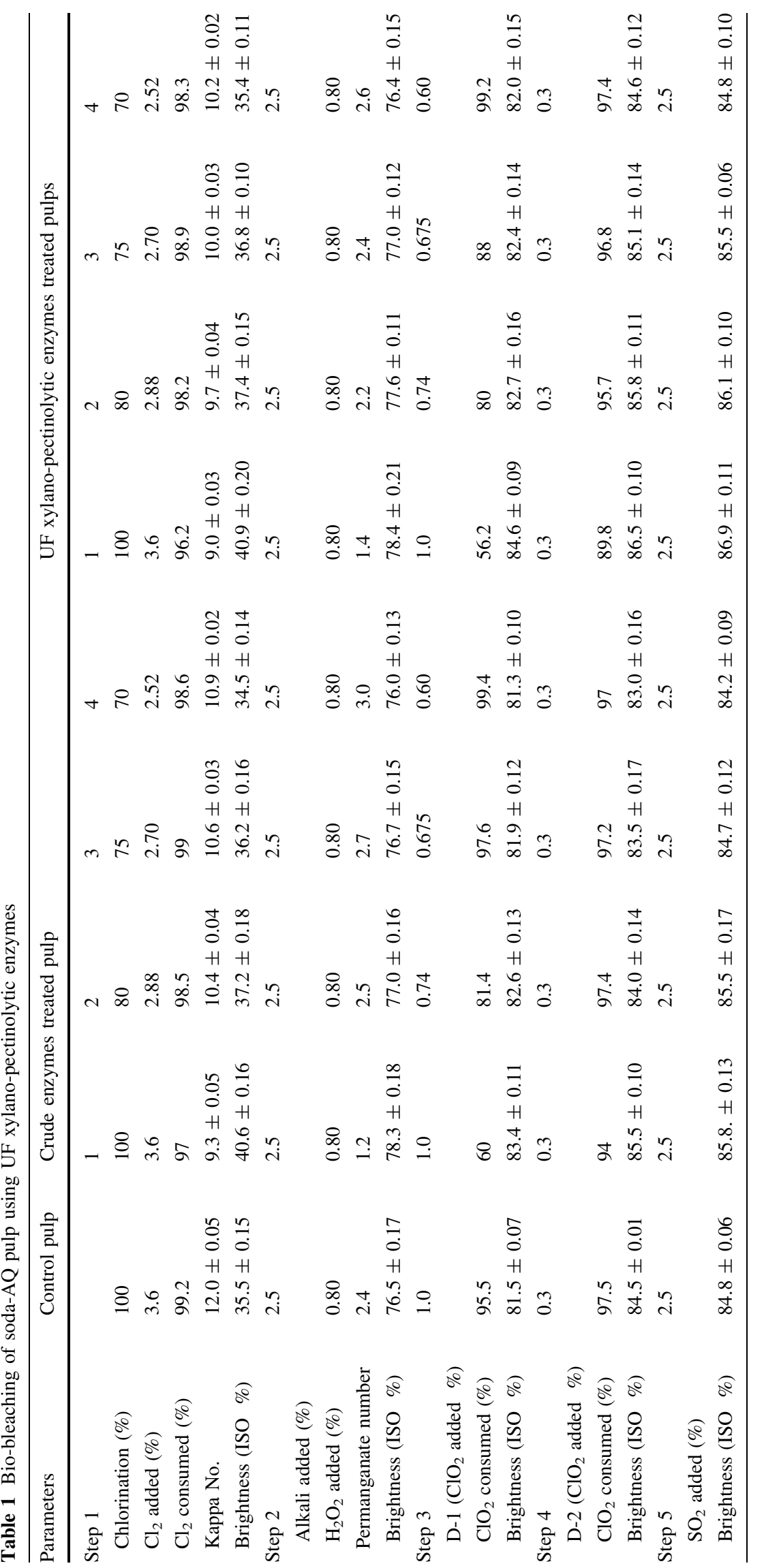




\section{Analysis of physical properties of biobleached pulp}

Significant improvement in various pulp properties, viz. viscosity, breaking length, burst factor, tear factor, and pulp freeness was observed using UF enzymes. Ultrafiltered enzyme-treated SAQ pulp bleached with $30 \%$ less chlorine resulted $11.87,10.71,17.42,14.55$, and $5.91 \%$ increase in pulp freeness, breaking length, burst factor, tear factor, and viscosity over control, respectively (Table 2). Agrawal et al. (2016) have reported 8.5, 13.4, 10.8, and $4.2 \%$ increase in breaking length, burst factor, tear factor, and viscosity, respectively, using crude xylanase-pectinase over control. Higher gains in all physical properties were observed using UF over crude enzymes, where a gain of $6.54 \%$ in pulp freeness, $2.1 \%$ in breaking length, $3.33 \%$ in burst factor, $3.02 \%$ in tear factor, $1.54 \%$ in viscosity was observed. This indicates that the quality of paper can be greatly improved by including only the fast flow rate, commercially feasible ultrafiltration step. Brightness of ultrafiltered enzymes plus chemically treated pulp was enhanced by about $2.1 \%$ in comparison with non-enzymetreated pulp. Agrawal et al. (2016) have reported nearly $1 \%$ increase in brightness in case of crude enzymes plus chemically treated pulp.

Biobleaching of wheat straw SAQ pulp using xylanase from Bacillus stearothermophilus SDX resulted in 4.70, $5.91,6.96$, and $13.15 \%$ increase in viscosity, burst factor, breaking length, and tear factor, respectively (Garg et al. 2011). Lin et al. (2013) reported 4.65, 9.3, and $13.95 \%$ increase in bursting index after treatment of wheat straw SAQ pulp with pulpzyme HC, recombinant xylanase from B. halodurans and commercial xylanase AU-PE89, respectively. Biobleaching of eucalyptus kraft pulp with xylanase producing $B$. halodurans FNP 135 culture and produced by $\mathrm{SmF}$ and SSF resulted in 8.6 and $3.3 \%$ increase in viscosity, 20.7 and $17.5 \%$ increase in tear factor, 13.7 and $12 \%$ increase in burst factor, and 8.7 and $6.7 \%$ increase in breaking length, respectively (Sharma et al. 2015). Biobleaching of eucalyptus kraft pulp using xylanase and laccase resulted in $13,49,6.9,23$, and $11.68 \%$ increase in brightness, breaking length, burst factor, tear factor, and viscosity, respectively(Gupta et al. 2015). A glimpse of producing superior quality paper from plywood waste using UF xylano-pectinolytic enzymes with reduced

Table 2 Different physical properties of biobleached soda-AQ pulp

\begin{tabular}{lccc}
\hline Pulp properties & Control & $\begin{array}{l}\text { Crude enzymes treated pulp } \\
\text { bleached with 25\% less chlorine }\end{array}$ & $\begin{array}{l}\text { UF enzymes treated pulp } \\
\text { bleached with 30\% less chlorine }\end{array}$ \\
\hline Breaking length (m) & $5460 \pm 6.1$ & $5920 \pm 5.1$ & $6045 \pm 6.2$ \\
Burst factor $(\mathrm{kPa} \mathrm{m} / \mathrm{g})$ & $13.2 \pm 0.4$ & $15.0 \pm 0.37$ & $15.5 \pm 0.25$ \\
Tear factor $\left(\mathrm{mN} \mathrm{m}^{2} / \mathrm{g}\right)$ & $53.6 \pm 0.43$ & $59.6 \pm 0.35$ & $61.4 \pm 0.28$ \\
Viscosity (cps) & $18.6 \pm 0.02$ & $19.4 \pm 0.07$ & $19.7 \pm 0.03$ \\
Pulp freeness $\left({ }^{0} \mathrm{SR}\right)$ & $16.0 \pm 0.03$ & $16.8 \pm 0.08$ & $17.9 \pm 0.06$ \\
\hline
\end{tabular}

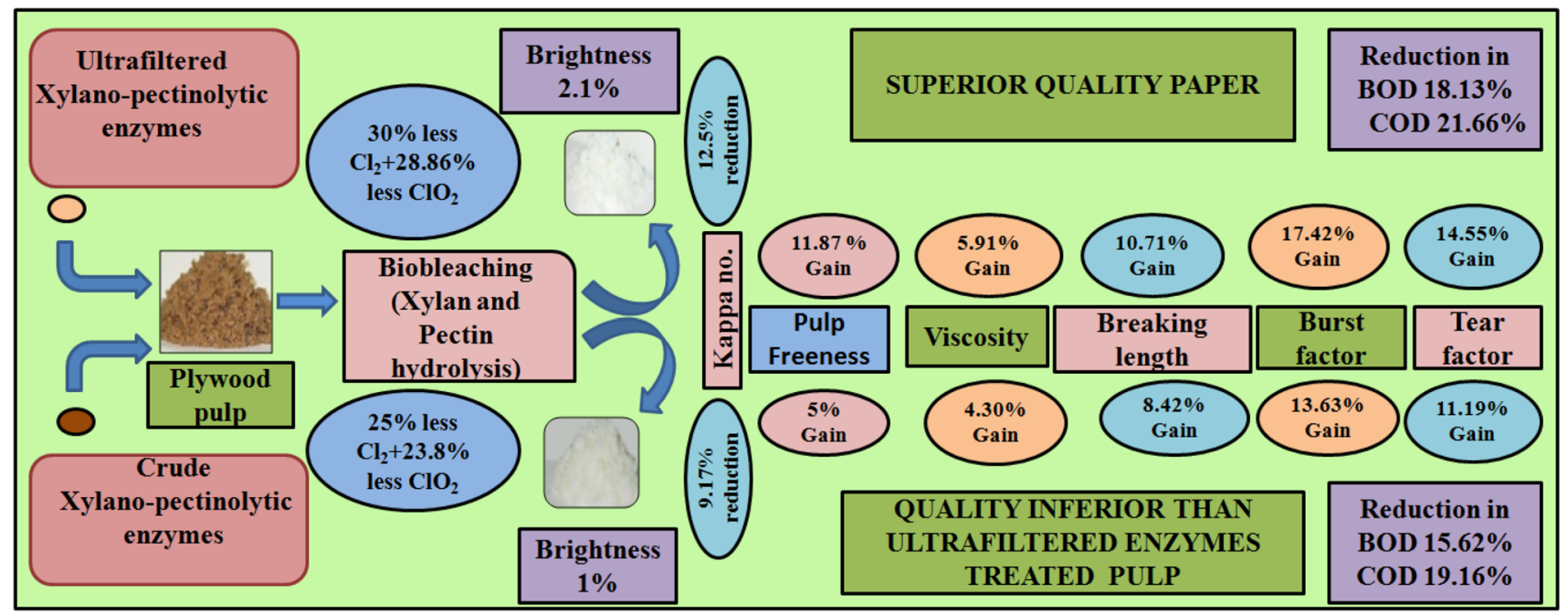

Fig. 2 Glimpse of producing superior quality paper from plywood waste using UF xylano-pectinolytic enzymes with reduced generation of pollution 
generation of pollution has been completely depicted in Fig. 2.

\section{Reduction in BOD and COD values of effluents}

Effluents released after biobleaching of SAQ pulp with UF enzymes at $30 \%$ less chlorination resulted in 2.62 and $9.4 \mathrm{~kg} /$ ton BOD and COD values in comparison with control (3.2 and $12.0 \mathrm{~kg} / \mathrm{ton})$. Effluents displayed 18.13 and $21.66 \%$ reduction in BOD and COD, whereas 15.62 and $19.16 \%$ (2.7 and $9.7 \mathrm{~kg} /$ ton) reduction in BOD and COD values of effluents was obtained after treating the SAQ plywood veneer pulp with crude enzymes in comparison with control.

\section{Conclusion}

This simple, novel, multi-benefit approach using ultrafiltered xylano-pectinolytic enzymes with low dose can be used to produce superior quality paper in an ecofriendly manner. This technology would also relieve the pressure on paper industries by generating less toxic effluent, which is the main area of concern these days. This new industrially feasible methodology seems to have great scope in paper industry.

Acknowledgements The authors gratefully acknowledge the financial support provided by the Department of Science and Technology, Government of Haryana, India (HSCST/2258). Kurukshetra University, Kurukshetra, India is gratefully acknowledged for providing laboratory facilities to accomplish the research work and also financial support in the form of University Research Scholarship to Divya Sharma.

\section{Compliance with ethical standards}

Conflict of interest The authors declare that they have no conflict of interest.

Open Access This article is distributed under the terms of the Creative Commons Attribution 4.0 International License (http:// creativecommons.org/licenses/by/4.0/), which permits unrestricted use, distribution, and reproduction in any medium, provided you give appropriate credit to the original author(s) and the source, provide a link to the Creative Commons license, and indicate if changes were made.

\section{References}

Agrawal S, Yadav RD, Mahajan R (2016) Synergistic effect of xylano-pectinolytic enzymes produced by a bacterial isolate in bleaching of plywood industrial waste. J Clean Prod 118:229-233. doi:10.1016/j.jclepro.2016.01.067

Andreu G, Vidal T (2014) An improved TCF sequence for biobleaching kenaf pulp: influence of the hexenuronic acid content and the use of xylanase. Bioresour Technol 152:253-258. doi:10.1016/j.biortech.2013.11.014

Bajpai P, Anand A, Sharma N, Mishra SP, Bajpai PK, Lachenal D (2006) Enzymes improve ECF bleaching of pulp. Bioresources 1(1):34-44

Beg QK, Kapoor M, Mahajan L, Hoondal GS (2001) Microbial xylanases and their industrial applications: a review. Appl Microbiol Biotechnol 56:326-338. doi:10.1007/s002530100704

Fiedler H, Hutzinger O, Timms CW (1990) Dioxins: sources of environmental load and human exposure. Toxicol Environ Chem 29(3):157-234. doi:10.1080/02772249009357628

Garg G, Dhiman SS, Mahajan R, Kaur A, Sharma J (2011) Bleachboosting effect of crude xylanase from Bacillus stearothermophilus SDX on wheat straw pulp. New Biotechnol 28(1):58-64. doi:10.1016/j.nbt.2010.07.020

Gupta V, Garg S, Capalash N, Gupta N, Sharma P (2015) Production of thermo-alkali-stable laccase and xylanase by co-culturing of Bacillus sp. and B. halodurans for biobleaching of kraft pulp and deinking of waste paper. Bioprocess Biosyst Eng 3:947-956. doi:10.1007/s00449-014-1340-0

Hossain K, Ismail N (2015) Bioremediation and detoxification of pulp and paper mill effluent: a review. Res $\mathrm{J}$ Environ Toxicol 9(3):113-134. doi:10.3923/rjet.2015.113.134

Hossain K, Rao AR (2014) Environmental change and its affect. Eur J Sustain Dev 3(2):89-96. doi:10.14207/ejsd.2014.r3n2p89

Kamali M, Khodaparsat Z (2015) Review on recent developments on pulp and paper mill wastewater treatment. Ecotoxicol Environ Saf 114:326-342. doi:10.1016/j.ecoenv.2014.05.005

Kaur A, Mahajan R, Singh A, Garg G, Sharma J (2010) Application of cellulase-free xylano-pectinolytic enzymes from the same bacterial isolate in biobleaching of kraft pulp. Bioresour Technol 101:9150-9155. doi:10.1016/j.biortech.2010.07.020

Lin X, Han S, Zhang N, Hu H, Zheng S, Ye Y, Lin Y (2013) Bleach boosting effect of xylanase A from Bacillus halodurans C-125 in ECF bleaching of wheat straw pulp. Enzyme Microb Technol 52:91-98. doi:10.1016/j.enzmictec.2012.10.011

Lund H, Pedersen HH, Xu H, Luo J (2004) Enzymatic treatment of paper making pulps. Patent No.WO 2004092479 A2

Miller GL (1959) Use of dinitrosalicylic acid reagent for determination of reducing sugar. Anal Chem 31(3):426-428. doi:10.1021/ ac60147a030

Nagar S, Jain RK, Thakur VV, Gupta VK (2013) Biobleaching application of cellulase poor and alkali stable xylanase from Bacillus pumilus SV-85S. 3. Biotech 3:277-285. doi:10.1007/ s13205-012-0096-y

Raj A, Kumar S, Haq I, Singh SK (2014) Bioremediation and toxicity reduction in pulp and paper mill effluent by newly isolated ligninolytic Paenibacillus sp. Ecol Eng 71:355-362. doi:10. 1016/j.ecoleng.2014.07.002

Sanghi A, Garg N, Kuhar K, Kuhad RC, Gupta VK (2009) Enhanced production of cellulase free xylanase by alkalophilic Bacillus subtilis ASH and its application in biobleaching of kraft pulp. Bioresources 4(3):1109-1129

Sharma P, Sood C, Singh G, Capalash N (2015) An eco-friendly process for biobleaching of eucalyptus kraft pulp with xylanase producing Bacillus halodurans. J Clean Prod 87:966-970. doi:10.1016/jclepro.2014.09.083

TAPPI test methods (1996) Technical Association of the Pulp and Paper Industry. TAPPI Press, Atlanta

Walia A, Mehta P, Guleria S, Shirkot CK (2015) Modification in the properties of paper by using cellulase-free xylanase in biobleaching of wheat straw pulp produced from alkalophilic Cellulosimicrobium cellulans CKMX1. Can J Microbiol 61(9):671-681. doi:10.1139/cjm-2015-0178 
Yin C, Goyal G, Trepow A, Kalka J (2011) Effect of low dose xylanase on pulp in prebleach treatment process. US Patent No.20110108222A1
Zhang X, Renaud S, Paice M (2008) Cellulase deinking of fresh and aged recycled newsprint/magazines (ONP/OMG). Enzyme Microb Tech 43:103-108. doi:10.1016/j.enzmictec.2007.11.005 